JEL: Q13, Q17

\title{
Zhang Fenghe
}

Sumy National Agrarian University, Ukraine Henan Institute of Science and Technology, China

\section{ANALYSIS OF THE CURRENT SITUATION OF AGRICULTURAL TRADE DEVELOPMENT BETWEEN CHINA AND UKRAINE}

Purpose. As a European granary, Ukraine has rich agricultural resources. China is a country with a large population and has a large demand for food. However, the agricultural trade between the two countries has only achieved rapid development in recent years, and is not closely linked in related trade areas. This article studies the current situation of agricultural trade between the two sides, analyzes the trade data, finds out challenges, and provides suggestions for further promoting trade cooperation between the two sides.

Methodology / approach. The categories 1, 2, 3, and 4 under the HS Code of the General Merchandise Trade Statistics Database of the People's Republic of China are used as agricultural trade statistics categories with a time span of 2014-2019 trade data. The relevant data of agricultural product trade are sorted and there is statistics, which objectively explain the current status of trade exchanges between the two sides; the results of the analysis of the trade data are put forward, and the problems existing in the development of China-Ukraine trade and the factors affecting the development are raised.

Results. According to the results of the analysis, from 2014 to 2019, China's agricultural products imported from Ukraine accounted for $45.5 \%$ of the total import trade. Agricultural products occupy a very important position in China's import trade from Ukraine in terms of trade scale. Among them, the import of cereals and other products accounted for $95.7 \%$ of the total imported plant products. Ukraine, the European granary, has become China's main food importer. In 2019, China replaced India as the largest food importer of Ukraine; In terms of export trade, mechanical and electrical products, base metals and light industrial products occupy an important position. From 2014 to 2019, China's agricultural exports to Ukraine accounted for only $2.6 \%$ of the total export trade, which is a small share. This shows that China and Ukraine have strong complementarity in terms of total trade volume and agricultural product trade. In the future, the two countries can further strengthen cooperation to expand their own advantages and better promote the development of trade between the two countries.

Originality / scientific novelty. Due to the geographical distance between China and Ukraine, the political instability of the post-independence republic as a former Soviet Union led to less economic and trade exchanges between Ukraine and China. Scientists did not study much on economic and trade relations between China and Ukraine. Most of the research deal with macro trade policy aspects, but the innovation of this article lies in the use of statistical data for empirical analysis, to show the current status of trade between the two sides, and to make recommendations for the further development of bilateral trade.

Practical value / implications. Since the establishment of diplomatic relations between China and Ukraine in 1992, the relations between the two countries have developed smoothly. In 2011, the two countries established a strategic partnership of cooperation. Subsequently, trade cooperation in various fields has continued to develop, especially in the agricultural product trade. In recent years, total agricultural trade has doubled. In 2019, China became the largest importer of Ukrainian agricultural products. After China proposed the implementation of the «Belt and Road» 


\section{Agricultural and Resource Economics}

www.are-journal.com

initiative, Ukraine actively participated in the «Belt and Road» framework agreement. The research on agricultural trade between the two sides will be of great significance to promote further and deeper cooperation between the two sides in the field of agricultural trade and expand and create a wider development space.

Key words: agricultural trade, total trade, export, import, China, Ukraine.

Introduction and review of literature. Agricultural resources are allocated worldwide through agricultural trade to meet different consumer needs. The development of agricultural trade has also promoted agricultural development and economic growth. China is the country with the largest population and the largest producer and consumer of agricultural products in the world. Agricultural products' trade plays an important role in foreign trade. Ukraine is an important agricultural place in the world and its agricultural resources are very developed. Since 2014, it has become the world's third largest food exporter and enjoys the reputation of «European granary». The relationship between China and Ukraine has developed smoothly since the establishment of diplomatic relations in 1992. In 2011, the two countries established a strategic cooperative partnership. Trade cooperation in various fields has continued to develop, especially in agricultural products. Due to the mutual complementarity between the two countries, the total agricultural product trade in recent years has increased. According to the Ukrainian News Agency, citing the National Scientific Centre «Institute of Agrarian Economics», the largest importer of Ukrainian agricultural products in 2019 was China, with a total value of 1.955 billion USD, accounting for $8.7 \%$ of Ukraine's total agricultural product exports, occupying the top spot for more than three consecutive years of India. After China proposed the implementation of the «Belt and Road» initiative, Ukraine actively participated in the construction of the «Belt and Road» initiative. My research on agricultural trade between the two sides is mainly to promote suggestions for further and deepening the cooperation between the two sides in the field of agricultural trade, and to expand and create a broader space for development.

Due to geographical reasons, China and Ukraine are far away from each other. Before Ukraine became independent, as a former republic of the Soviet Union, there were fewer economic and trade exchanges with China. There are not much research on economic and trade relations between China and Ukraine. After independence, the structure of trade products has been continuously upgraded, which has expanded trade relations with other countries. In particular, Ukraine has taken advantage of its relatively abundant agricultural resources to vigorously develop agricultural product export trade. The issues related to agricultural trade have become the object of much scientific research. In important research at the national and global levels covering this issue, follow-up work should be emphasized.

Boysen-Urban et al. (2020) based on the Mercantilist Trade Restriction Index (MTRI), established an overall trade impact index that measured domestic support payments. By analyzing the development of domestic support payment trade restrictions over time and between countries, assessing agricultural policy reforms, 


\section{Agricultural and Resource Economics}

www.are-journal.com

the results confirmed that the EU's agricultural trade had decreased due to decoupling support for agriculture. The protection of agricultural trade depends on the degree of decoupling of agriculture.

Protecting the environment, avoiding the deterioration of the agricultural production environment, reducing losses and waste can effectively ensure the supply of agricultural products such as grain. At present, increasing production is still the main strategy for the supply of agricultural products in Ukraine. It has a positive impact on social stability and leads to an increase in the economic aggregate (Kotykova and Babych, 2019).

The effect of Tunisian exchange rate changes on the net external position of the agricultural sector is studied. It shows that the substitutability of production and consumption in domestically produced goods can lead to ambiguous effects due to conditions beyond the Marshall-Lerner condition (Chebbi and Olarreaga, 2019).

Carey (2019) evaluated the European Commission's June 2018 legislative proposal on Common Agricultural Policy (CAP) after 2020, considered the European Commission's new delivery model (NDM) from the perspective of national governments, and considered that national administration Departments need to simplify and streamline reporting procedures for agricultural policies, transitioning from compliance monitoring to performance monitoring.

Nagyová et al. (2018) believes that the development of foreign trade is crucial to the stability of the national economy, and it can be considered as a confirmation of the actual efficiency of the national economy and its ability to compete in the global economy. By analyzing the development of the export of goods between Ukraine and Visegrad countries from 2002 to 2013, it was found that Ukraine's export business was affected by the per capita GDP of other trading partner countries, and that export trade could promote domestic GDP growth. Ukraine's exports are dominated by agricultural products to a large extent. Ukraine should formulate a smart trade strategy and expand its current export activities to Visegrad countries. It should integrate more deeply into the EU market.

Ivanyshyn, Bilyk and Kucher (2018) inspected the current status of organic agricultural production in Ukraine, and studied the natural environment, climate, soil potential and export prospects of organic agricultural production, and considered that the development of organic agricultural production was Ukrainian economic agriculture one of the departments main priorities and that with the deterioration of the production environment of agricultural products, people would pay more attention to healthy and safe food, and the demand wouldn't continue to increase. The key to effective national implementation of this strategy is to increase investment in financial resources, and to use effective marketing strategies to promote and sell organic agricultural products in domestic and foreign markets.

By studying the sustainable development theories and methods of the agricultural sector in specific regions, it is believed that with the laws and regulations on sustainable agricultural development, it proposes to build regional sustainable agricultural development. The effective management system summarizes all the 


\section{Agricultural and Resource Economics}

www.are-journal.com

actions of agricultural relationship management subjects into the following elements: state supervision, market self-organization, and agricultural sector management. Actively utilize innovative resources and make more effective use of natural, financial and other resources as supplementary resources, so as to promote the balanced development of resources and technology in the direction of production growth to promote the sustainable development of regional agricultural systems (Kozlovskyi et al., 2017).

Based on the evaluation of the historical development of the three major economic systems of agricultural product prices, insurance, and futures in China's agricultural production, this paper studies the government's transition from centrally planned procurement to provincial variable agricultural production models. The provincial target price mechanism established by China during the year resulted in the establishment of a minimum purchase price mechanism for agricultural products by the country, which provided certain subsidy measures for agricultural production, which could effectively protect agricultural production and promote the development of agricultural trade (Kenderdine, 2018).

Wang et al. (2018) quantitatively analyzed the development trend and current situation of global agricultural trade by using the international trade data of 57 types of agricultural products from six major categories of cereals, oil crops, sugar, fiber, fruits, vegetables and meat from 1986 to 2013. The results showed that the number of global agricultural importing and exporting countries participating in the agricultural trade network was increasing, and agricultural trade links between countries were becoming closer, and China should open wider. Expand the sources of agricultural import and export, and actively participate in international trade in agricultural products. At the same time, we must strengthen our national agricultural infrastructure, increase agricultural productive capacity, prevent risks, and ensure national food security.

O'Donoghue, Roantree and Mccarren (2017) believes that agricultural analytics will become an emerging sector in the future. It can mine agricultural data, predict and analyze hidden trends and events, and make decisions for the agricultural sector provide information.

Due to the increase of internal uncertainties in integrated agricultural trading enterprises, taking German agricultural trade industry management decisions as an example, using qualitative research and design, conducting in-depth interviews with industry experts, and determining national farming Trade policy and other factors are the decisive factors influencing agricultural trade risk decisions (Gollisch, Hedderich and Theuvsen, 2016).

Chand and Saxena (2017) investigated the agricultural trade between India and Pakistan and concluded that despite the neighboring advantages between the two countries, the agricultural trade between India and Pakistan did not begin until the late 1990s. Entering the 21st century especially after the SAFTA came into effect in 2006, the agricultural trade between the two countries has developed rapidly and the agricultural trade between the two countries is highly complementary. However, 


\section{Agricultural and Resource Economics}

www.are-journal.com

despite the fact that both countries have joined SAFTA, the existence of tariff and non-tariff barriers has restricted the continued expansion of agricultural trade between the two countries obstacles to development.

The increase in export potential is a factor that increases a country's competitiveness in the global market. The «Belt and Road» initiative is considered as a tool for China to implement diversification of its outward-oriented economic and trade policies. By analyzing the advantages and disadvantages of China's agricultural product export from 1995 to 2015, and grouping them according to the competitiveness of agricultural products and food, it is pointed out that China should further improve the policies and measures for developing or establishing competitive advantages in the «Belt and Road» initiative (Erokhin and Gao, 2018).

It is believed that China, as a major agricultural country, has ushered in rapid development in agriculture after joining the WTO, but some developed countries have continuously improved environmental protection standards in order to protect their own interests and set up green trade barriers. It caused a sharp decline in China's agricultural exports (Tao, 2016).

It is believed that the specialization of agricultural systems may lead to an imbalance between economic benefits and ecosystems. The improvement of agricultural specialization can promote the development of agricultural trade and increase agricultural income, but more agriculture specialization may reduce biodiversity and unbalance ecosystems (Klasen et al., 2016).

It is believed that agricultural safety incidents (such as Mad Cow Disease, excessive pesticide residues, etc.) have seriously affected agricultural production, and even caused a great negative impact on people's economic and social life. The agricultural product traceability system constructed through the internet of things technology and information security technology can effectively understand the detailed process and risk status of each stage in the process of controlling agricultural product growth and production, and can provide an effective basis for agricultural product trade security (Yongbin and Cao, 2017).

By analyzing Ukraine's position in the world's agricultural production and export rankings and the share of agricultural and food industry products in the world, it was determined that the main markets for Ukrainian agricultural exports were Europe and growing Asia. Make a list of the most profitable agricultural products in Ukraine, and find out the main factors that affect Ukrainian agricultural trade, including agricultural trade policies (Kiforenko, 2016).

The Ukrainian government attaches great importance to the agricultural development of the country and hopes that the agricultural economy will become the engine of national economic development. However, agricultural enterprises cannot play a key role in achieving rural social balance and environmental protection goals. This requires the government to adopt a more balanced agricultural policy to provide development opportunities and survival means for rural residents, maintain ecological balance, restore soil fertility, and protect rural landscapes (Borodina and Krupin, 2017). 


\section{Agricultural and Resource Economics}

www.are-journal.com

Murova (2015) analyzed the current land legislation and policies in Ukraine, studies its impact on the technical efficiency of crop production, and concluded that the extent to which agricultural enterprises lease and lease agricultural land was the largest impact on agricultural production efficiency factor.

Lysak and Andreeva (2017) studied the current agricultural export situation in Ukraine, analyzed the advantages and disadvantages of agricultural export after the signing of the Union Agreement with the EU, and the need to simplify export procedures with other countries According to the development of Ukrainian agricultural exports, the Asian and European markets were determined as the strategic development direction of Ukrainian agricultural exports.

The purpose of the article. As a large country with a large population, China has a very large demand for agricultural products, and imports of agricultural products are also very large. As a «European granary», Ukraine has good agricultural development resources and provides a large amount of food for Europe and other regions. However, the agricultural trade between China and Ukraine has only achieved rapid development in recent years, and the related trade areas are not closely linked. This article mainly uses the data released by the General Administration of Customs of China to analyze the international trade and agricultural product trade conditions of China and Ukraine from 2014 to 2019, find breakthrough points, and provide countermeasures and suggestions for further promoting bilateral agricultural product trade cooperation.

Research methodology. It was used statistical analysis method to collect statistics on China and Ukraine's trade and agricultural product trade data to objectively explain the current status of trade exchanges between the two sides; quantitative and qualitative analysis methods combined with the results of trade data analysis to propose the existence of Sino-Ukraine trade development Problems and factors affecting development. The data used in this article are from the Commodity Trade Statistics Database of the General Administration of Customs of the People's Republic of China. Categories 1, 2, 3, and 4 under the HS classification code were used as agricultural trade statistics categories with a time span of 2014-2019.

Results and discussion. 1. China's total import trade with Ukraine and imports of agricultural products. During the analyzed period, China's total imports from Ukraine and agricultural products showed an overall growth trend. Since 2014, China's total imports from Ukraine and its agricultural products trade have generally shown a steady increase. So, from 2014 to 2019, China's total imports from Ukraine reached 17671 million USD, and the total amount of imported agricultural products was 8037 million USD. Imported agricultural products accounted for $45.5 \%$ of the total import trade. In terms of trade scale, agricultural products were imported from Ukraine to China. Trade occupies a very important position. Looking at the vertical dimension, only imported agricultural products accounted for $21.8 \%$ of the total import trade in 2014. In 2015, the proportion was rapidly increased to $48.23 \%$. After that, only in 2017 it was temporarily fallen to $48.4 \%$, and the rest $(2016,2018$ and 2019) each accounted for more than $50.0 \%$. From the vertical dimension of trade 
exchanges, agricultural trade has achieved rapid development in China's import trade from Ukraine. To understand from a reverse perspective, as a large agricultural country with rich agricultural resources, Europe's granary exports of its agricultural products have begun to have an important impact on Asia and China, and agricultural products have become the basis of trade between China and Ukraine (Table 1).

China's agricultural products trade and total trade from Ukraine

Table 1 from 2014 to 2019

\begin{tabular}{|c|c|c|c|c|}
\hline Years & $\begin{array}{c}\text { Imported } \\
\text { agricultural } \\
\text { products, thsd. } \\
\text { USD }\end{array}$ & $\begin{array}{c}\text { Total imports, } \\
\text { thsd. USD }\end{array}$ & $\begin{array}{c}\text { Ratio of imported } \\
\text { agricultural } \\
\text { products to total } \\
\text { imports, } \%\end{array}$ & $\begin{array}{c}\text { Imports of } \\
\text { agricultural } \\
\text { products increased } \\
\text { sequentially, \% }\end{array}$ \\
\hline 2014 & 762045 & 3486016 & 21.86 & 1.00 \\
\hline 2015 & 1060612 & 2199279 & 48.23 & 39.18 \\
\hline 2016 & 1268980 & 2487605 & 51.01 & 19.64 \\
\hline 2017 & 1131278 & 2335614 & 48.44 & -10.85 \\
\hline 2018 & 1373898 & 2648477 & 51.88 & 21.45 \\
\hline 2019 & 2439980 & 4513702 & 54.06 & 77.60 \\
\hline Total & 8036793 & 17670693 & 45.48 & - \\
\hline
\end{tabular}

Source: formed and calculated by the author based on data of Commodity Trade Statistics Database of the General Administration of Customs of the People's Republic of China.

China's total trade from Ukraine consists mainly of agricultural and mineral products. From the perspective of China's import volume from Ukraine during the analyzed period, agricultural and mineral products are the main products. As we noted, during 2014-2019, imported agricultural products accounted for $45.5 \%$ of the total import trade, and imported mineral products accounted for $21.5 \%$ of the total import trade. China's export trade is mainly based on raw material resources. From a reverse perspective, Ukraine's range of Chinese goods is relatively narrow, but the advantages of export goods are obvious.

Classification of China's agricultural imports from Ukraine. From the perspective of trade scale, China's agricultural products imported from Ukraine are mainly category 2 plant products and category 3 animal and vegetable oils, refined edible oils and fats. From 2014 to 2019, imported plant products totaled 4023 million USD. Refined edible fats and oils totaled 3328 million USD; they accounted for $50.0 \%$ and $41.4 \%$ of the total imported agricultural products, respectively. Among the imported plant products, cereals were the main products, accounting for $95.7 \%$ of the total imported plant products. China has become the Ukrainian food major importing countries (Table 2).

2. China's total export trade with Ukraine and exports of agricultural products. During the analyzed period, China's total exports to Ukraine and its agricultural products showed a trend of first decrease and then increase. China's total exports to Ukraine and its agricultural products declined significantly in 2015 compared to 2014. The total value of China's export trade to Ukraine in 2015 was 3516.6 million USD, and in 2014 it was 5108.0 million USD, a decrease of $31.2 \%$ in 2015 


\section{Agricultural and Resource Economics}

www.are-journal.com

compared to 2014. The agricultural products exported by China to Ukraine were 2015 84.4 million USD, a $43.6 \%$ decrease in 2015 compared to 2014. As we know, in 2014, the political situation in Ukraine has undergone tremendous changes. The changes in the political situation have had a significant impact on foreign trade policies and directly led to a decline in trade volume.

Table 2

Classification of China's agricultural imports from Ukraine from 2014 to 2019, thsd. USD

\begin{tabular}{|l|c|c|c|c|c|c|}
\hline \multicolumn{1}{|c|}{ Coding } & 2014 & 2015 & 2016 & 2017 & 2018 & 2019 \\
\hline 1. Animal products & 1748 & 456 & 3793 & 17088 & 31128 & 46981 \\
\hline 02 Meat and edible offal & - & - & - & 130 & - & 1265 \\
\hline 03 Fish, Aquatic animals & 59 & 16 & - & - & - & 821 \\
\hline 04 Milk, eggs, honey, etc. & - & 336 & 2319 & 12789 & 20000 & 31014 \\
\hline 05 Other animal products & 1689 & 105 & 1474 & 4169 & 11128 & 13881 \\
\hline 2. Plant products & 301987 & 658918 & 575192 & 554855 & 772268 & 1160160 \\
\hline 01 Living plant & - & - & - & - & - & 2 \\
\hline 03 Edible fruits and nuts & 1552 & 239 & 399 & 1641 & 2786 & 10010 \\
\hline 04 Coffee and tea & - & 9 & - & - & 13 & 9 \\
\hline 05 Cereals & 290672 & 653099 & 570256 & 518263 & 731964 & 1085913 \\
\hline 06 Malt, starch, etc. & 5845 & 1820 & 399 & 22659 & 34094 & 52179 \\
\hline 07 Oilseeds, kernels, feed & 3918 & 3751 & 4138 & 12258 & 3220 & 12046 \\
\hline 08 Gum, resin, etc. & - & - & - & - & - & 1 \\
\hline 09 Knitting plant material & - & - & - & 35 & 190 & - \\
\hline $\begin{array}{l}\text { 3. Animal and vegetable oils, } \\
\text { edible oils and fats }\end{array}$ & 450863 & 396445 & 681154 & 548749 & 444402 & 806588 \\
\hline $\begin{array}{l}\text { 4. Food, Beverages, wine and } \\
\text { tobacco }\end{array}$ & 7447 & 4793 & 8840 & 10586 & 126100 & 426251 \\
\hline 01 Meat and aquatic products & 81 & - & - & - & 368 & 2478 \\
\hline 02 Sugar confectionery & 2250 & 1438 & 2853 & 3523 & 5127 & 5373 \\
\hline 03 Cocoa products & 2504 & 2012 & 2077 & 2106 & 2059 & 3560 \\
\hline 04 Cereal flour, starch & 470 & 322 & 1196 & 1074 & 2118 & 3698 \\
\hline 05 Vegetable and fruit products & 82 & 158 & 131 & 397 & 283 & 514 \\
\hline 06 Miscellaneous food & 10 & 23 & 11 & 80 & 395 & 862 \\
\hline 07 Drinks, wine and vinegar & 2051 & 840 & 2573 & 2067 & 4457 & 3807 \\
\hline $\begin{array}{l}\text { 08 Food industry residues and } \\
\text { waste }\end{array}$ & - & - & - & 1340 & 111293 & 403748 \\
\hline 09 Tobacco and tobacco products & - & - & - & - & - & 2211 \\
\hline
\end{tabular}

Source: formed by the author based on data of Commodity Trade Statistics Database of the General Administration of Customs of the People's Republic of China. («-» indicates that no import trade has taken place).

With the stability of Ukraine's political situation in 2015, China's total export trade to Ukraine and agricultural products trade have resumed steady growth year by year. From 2014 to 2019, China's total export trade to Ukraine reached 7399.8 million USD, an increase of $44.9 \%$ over 2014.

The export volume of agricultural products in 2019 was 201.1 million USD, an increase of $138.3 \%$ over 2015. From the vertical dimension of trade exchanges, 
agricultural products trade accounted for only a small proportion of China's total export trade to Ukraine from 2014 to 2019. For example, during the analyzed period, the largest export of agricultural products in 2019 only accounted for $2.7 \%$ of the total export trade, which showed that China and Ukraine did not have competition in agricultural trade, but there was greater complementarity (Table 3).

Table 3

China's agricultural exports to Ukraine and total trade from 2014 to 2019

\begin{tabular}{|c|c|c|c|c|}
\hline Years & $\begin{array}{c}\text { Exported } \\
\text { agricultural } \\
\text { products, thsd. } \\
\text { USD }\end{array}$ & $\begin{array}{c}\text { Total exports, } \\
\text { thsd. USD }\end{array}$ & $\begin{array}{c}\text { Ratio of exported } \\
\text { agricultural } \\
\text { products to total } \\
\text { exports, } \%\end{array}$ & $\begin{array}{c}\text { Exports of } \\
\text { agricultural } \\
\text { products increased } \\
\text { sequentially, \% }\end{array}$ \\
\hline 2014 & 149678 & 5107956 & 2.93 & 1.00 \\
\hline 2015 & 84383 & 3516584 & 2.40 & -18.09 \\
\hline 2016 & 109503 & 4216822 & 2.60 & 8.33 \\
\hline 2017 & 133415 & 5041077 & 2.65 & 1.92 \\
\hline 2018 & 177893 & 7019004 & 2.53 & -4.53 \\
\hline 2019 & 201103 & 7399836 & 2.72 & 7.51 \\
\hline Total & 855975 & 32301279 & 2.65 & - \\
\hline
\end{tabular}

Source: formed and calculated by the author based on data of Commodity Trade Statistics Database of the General Administration of Customs of the People's Republic of China.

China's export trade to Ukraine is mainly mechanical and electrical products, base metals and products, light industrial products, etc. During the analyzed period, China's exports to Ukraine were mainly mechanical and electrical products, base metals and products, chemical products, and light industrial products such as shoes, and umbrellas. From 2014 to 2019, China's exports of mechanical and electrical products to Ukraine accounted for $42.3 \%$ of the total export trade, and exports of base metals and products accounted for $20.3 \%$ of the total trade. At present, China exports to Ukraine mechanical and electrical products, base metals and products, textiles and raw materials. The largest import source of country is ceramics, glass products, shoes, hats, umbrellas and other light industrial products.

Classification of China's agricultural exports to Ukraine. From the perspective of trade scale, China's agricultural products exported to Ukraine are mainly meat, aquatic animal products in category 4 , vegetables, fruit products, and fish in category 1 aquatic animals; from 2014 to 2019, exports were 223.1 million USD, 111.9, and 97.8 million USD, respectively, accounting for $26.0 \%, 13.1 \%$, and $11.4 \%$ of China's total agricultural exports to Ukraine. According to statistical analysis, China's agricultural products exported to Ukraine are mainly meat, fish and other aquatic animals and products, and vegetables and fruit products. Compared with China's main agricultural products imported from Ukraine, such as cereals, animals and vegetable oils, the two countries trade in agricultural products. There are large differences in categories, and agricultural trade exchanges are highly complementary, which provides a broad space for the two sides to further expand the development of agricultural trade (Table 4). 
Classification of China's agricultural exports to Ukraine from 2014 to 2019, thsd. USD

\begin{tabular}{|l|c|c|c|c|c|c|}
\hline \multicolumn{1}{|c|}{ Coding } & 2014 & 2015 & 2016 & 2017 & 2018 & 2019 \\
\hline 1. Animal products & 13138 & 10246 & 18591 & 23301 & 34197 & 29990 \\
\hline 01 Live animals & - & 1 & 2 & 3 & - & 1 \\
\hline 02 Meat and edible offal & 53 & - & - & 170 & - & 27 \\
\hline 03 Fish Aquatic animals & 12031 & 7740 & 13832 & 17215 & 25436 & 21619 \\
\hline 04 Milk, eggs, honey, etc. & 1 & - & 5 & 4 & 3 & 2 \\
\hline 05 Other animal products & 1053 & 2505 & 4752 & 5910 & 8758 & 8340 \\
\hline 2. Plant products & 19263 & 24823 & 25422 & 27766 & 36532 & 42646 \\
\hline 01 Living plant & 19 & 18 & 9 & 7 & 42 & 9 \\
\hline 02 Edible vegetables & 2564 & 5775 & 6867 & 5116 & 3846 & 6749 \\
\hline 03 Edible fruits and nuts & 2396 & 2320 & 2839 & 4608 & 6261 & 11110 \\
\hline 04 Coffee and tea & 6238 & 6279 & 7399 & 7647 & 8509 & 8299 \\
\hline 05 Cereals & - & - & - & - & 4545 & 2725 \\
\hline 06 Malt, starch, etc. & 274 & 392 & 576 & 32 & 33 & 38 \\
\hline 07 Oilseeds, kernels, feed & 1340 & 1172 & 937 & 1126 & 803 & 966 \\
\hline 08 Gum, resin, etc. & 6211 & 8688 & 6516 & 9014 & 12247 & 12624 \\
\hline 09 Knitting plant material & 219 & 179 & 280 & 217 & 245 & 125 \\
\hline $\begin{array}{l}\text { 3. Animal and vegetable oils, } \\
\text { edible oils and fats }\end{array}$ & 59 & 111 & 229 & 368 & 209 & 243 \\
\hline $\begin{array}{l}\text { 4. Food, Beverages, wine and } \\
\text { tobacco }\end{array}$ & 59452 & 49203 & 65261 & 81980 & 106955 & 128224 \\
\hline 01 Meat and aquatic products & 28006 & 15312 & 29169 & 33549 & 48410 & 68653 \\
\hline 02 Sugar confectionery & 2969 & 3552 & 3290 & 3107 & 4723 & 4018 \\
\hline 03 Cocoa products & 58 & 44 & 68 & 58 & 261 & 422 \\
\hline 04 Cereal flour, starch & 690 & 515 & 891 & 507 & 863 & 1231 \\
\hline 05 Vegetable and fruit products & 16297 & 10101 & 12349 & 25410 & 22506 & 25209 \\
\hline 06 Miscellaneous food & 5390 & 5928 & 5368 & 4512 & 9438 & 8336 \\
\hline 07 Drinks, wine and vinegar & 78 & 50 & 26 & 561 & 2349 & 3176 \\
\hline $\begin{array}{l}\text { 08 Food industry residues and } \\
\text { waste }\end{array}$ & 5426 & 8679 & 9050 & 11152 & 16811 & 15686 \\
\hline 09 Tobacco and tobacco products & 538 & 5022 & 5050 & 3124 & 1594 & 1493 \\
\hline
\end{tabular}

Source: formed by the author based on data of Commodity Trade Statistics Database of the General Administration of Customs of the People's Republic of China («-» indicates that no export trade has taken place).

Conclusions. With the rapid development of bilateral trade between China and Ukraine, China has become the sixth largest export market for Ukraine and the second largest source of imports after Russia. As one of the countries that responded to China's initiative to promote the «Belt and Road» initiative, Ukraine has become one of the first batch of countries identified along the «Belt and Road», which will open a wider space for the rapid development of bilateral trade between China and Ukraine in the future; According to the «Ukraine 2017-2021 Trade Strategy Development Roadmap» issued by Ukraine, China will become the main market for Ukrainian trade exports in the future. Judging from the total value of China's import and export trade with Ukraine and agricultural product trade from 2014 to 2019, the 


\section{Agricultural and Resource Economics}

www.are-journal.com

trade between China and Ukraine is highly complementary. In the future, the trade development potential of the two countries is huge, and the trade structure will continue to be optimized. To this end, the following measures should be taken to continue to promote the development of China-Ukraine trade in the future:

(i) accelerate the development of inter-industry trade. Although the scale of China-Ukraine bilateral trade is accelerating at this stage, the trade between the two sides is mainly based on inter-industry trade based on the comparative advantages caused by differences in natural factors. The products that China exports to Ukraine are mainly electromechanical products and aquatic products of meat, fish and their products. In the future, the trade between the two countries will continue to be dominated by inter-industry trade. The complementarity between the two countries in economic development and industrial products should be further utilized to expand the scale of trade.

(ii) continuously optimize the structure of trade products. The optimization of the trade structure is conducive to expanding the scale of trade between the two sides. In recent years, with the continuous development of production technologies and processes in the two countries, China's export trade to Ukraine has increased rapidly, with the largest increase in transportation equipment. Many light industrial products such as shoes and umbrellas have gradually declined; China's import trade from Ukraine has seen the diversification of imported goods such as steam turbines, ship propulsion systems and engine generators, while traditional base metals and their products are a downward trend. The optimization of the trade product structure has promoted the development of trade between the two sides. China has become Ukraine's largest exporter and second largest source of imported products in Asia.

(iii) continue to attach importance to the development of China-Ukraine agricultural trade. Ukraine is a large agricultural country with abundant agricultural resources. It has the largest black soils in the world and is rich in many types of agricultural products. China is a country with a large population and a large consumer of agricultural products. It has a considerable demand for food. Compared with Ukraine, China has advantages in agriculture in terms of labor force, capital, technical processing of agricultural products, and logistics operations. The two sides also have strong complementarities in the types of agricultural products trade. Therefore, agricultural products have been imported from Ukraine. Strengthening agricultural technology exchanges and cooperation and increasing the added value of agricultural products are the trends of mutually beneficial development of agricultural products trade between the two sides in the future.

Future research recommendations on agricultural trade between China and Ukraine. In 2019, China has become Ukraine's largest agricultural product importer. In order to further strengthen the development of agricultural trade between the two sides and promote deep cooperation between the two sides, the focus of future research is: within the framework of the «Belt and Road» initiative China should actively expand investment in the Ukrainian agricultural industry and provide agricultural technology support; Ukraine should introduce preferential tariff measures 


\section{Agricultural and Resource Economics}

www.are-journal.com

to improve the investment environment for foreign investors; establish agricultural cooperation parks and other measures to achieve sustainable development of agricultural trade between the two sides.

\section{References}

1. Boysen-Urban, K., Brockmeier, M., Jensen, H. G. and Boysen, O. (2020), Measuring the trade restrictiveness of domestic support using the EU Common agricultural policy as an example. Journal of Agricultural Economics, vol. 71, no. 1, pp. 27-49. https://doi.org/10.1111/1477-9552.12337.

2. Kotykova, O. and Babych, M. (2019), Limitations in availability of food in Ukraine as a result of loss and waste. Oeconomia Copernicana, vol. 10, no. 1, pp. 153-172. https://doi.org/10.24136/oc.2019.008.

3. Chebbi, H. E. and Olarreaga, M. (2019), Investigating exchange rate shocks on agricultural trade balance: the case of Tunisia. Journal of international trade \& economic development, vol. 28, no. 5, pp. 628-647. https://doi.org/10.1080/09638199.2019.1572774.

4. Carey, M. (2019), The Common agricultural policy's new delivery model post20: national administration perspective. EuroChoices, vol. 18, no. 1, pp. 11-17. https://doi.org/10.1111/1746-692X.12218.

5. Nagyová, L., Horáková, M., Moroz, S., Horská, E. and Poláková, Z. (2018), The analysis of export trade between Ukraine and Visegrad countries. Economy and Management, vol. 21, no. 2, pp. 115-132. https://doi.org/10.15240/tul/001/2018-2008.

6. Ivanyshyn, V., Bilyk, T. and Kucher, O. (2018), Marketing strategy formation for the development of organic production in the Ukraine. Economic Sciences for Agribusiness and Rural Economy, vol. 1, pp. 34-39. https://doi.org/10.22630/ESARE.2018.1.3.

7. Kozlovskyi, S., Grynyuk, R., Baltremus O. and Ivashchenko, A. (2017), The methods of state regulation of sustainable development of agrarian sector in Ukraine. Problems and Perspectives in Management, vol. 15, no. 2-2, pp. 332-343. https://doi.org/10.21511/ppm.15(2-2).2017.03.

8. Kenderdine, T. (2018), Insurance plus futures: agricultural commodity price reform in China. Asia \& the Pacific Policy Studies, vol. 5, no. 2, pp. 331-346. https://doi.org/10.1002/app5.226.

9. Wang, X., Qiang, W., Niu, S., Liu, A., Cheng, S., Li, Z. (2018), Analysis on global agricultural trade network and its evolution. Journal of Natural Resources, vol. 33, no. 6, pp. 940-953. https://doi.org/10.31497/zrzyxb.20180403.

10. O'Donoghue, J., Roantree, M. and McCarren, A. (2017), Detecting feature interactions in agricultural trade data using a deep neural network in Big Data Analytics and Knowledge Discovery, eds. L. Bellatreche, S. Chakravarthy. Lecture Notes in Computer Science, vol. 10440. Springer, Cham. https://doi.org/10.1007/9783-319-64283-3_33.

11. Gollisch, S., Hedderich, B. and Theuvsen, L. (2016), Reference points and risky decision-making in agricultural trade firms: a case study in Germany, 
www.are-journal.com

Diskussionsbeitrag, No. 1609, Georg-August-Universität Göttingen, Department für Agrarökonomie und Rurale Entwicklung (DARE), Göttingen.

12. Chand, R. and Saxena, R. (2017), Agricultural trade between India and Pakistan: status and potential. India-Pakistan Trade Normalisation in India-Pakistan Trade Normalisation, eds. N. Taneja, I. Dayal, Springer, Singapore. https://doi.org/10.1007/978-981-10-2215-9_2.

13. Erokhin, V. and Gao, T. (2018), Competitive advantages of China's agricultural exports in the Outward-Looking Belt and Road Initiative in China's Belt and Road Initiative, eds. W. Zhang, I. Alon, C. Lattemann. Palgrave Studies of Internationalization in Emerging Markets. Palgrave Macmillan, Cham. https://doi.org/10.1007/978-3-319-75435-2_14.

14. Tao, L. (2016), Green trade barriers with our country agricultural product export trade. Science Innovation, vol. 4, no. 3, pp. 168-171. https://doi.org/10.11648/j.si.20160403.19.

15. Klasen, S., Meyer, K. M., Dislich, C. (2016), Economic and ecological trade-offs of agricultural specialization at different spatial scales. Ecological Economics, vol. 122, pp. 111-120. https://doi.org/10.1016/j.ecolecon.2016.01.001.

16. Zhao, Y. and Cao, N. (2017), Research on traceability of agricultural products based on internet of things, 2017 IEEE International Conference on Computational Science and Engineering (CSE) and IEEE International Conference on Embedded and Ubiquitous Computing (EUC), Guangzhou, pp. 414-417. https://doi.org/10.1109/CSE-EUC.2017.264.

17. Kiforenko, O. (2016), Agroholdings as the subjects of the economy globalization - the example of Ukraine. Problems of World Agriculture, vol. 16(31), pp. 169-178. https://doi.org/10.22004/ag.econ.253051.

18. Borodina, O. and Krupin, V. (2017), Is it possible to utilise the agricultural potential of Ukraine under the current agrarian system? Euro Choices, vol. 17, no. 1, pp. 46-51. https://doi.org/10.1111/1746-692X.12151.

19. Murova, O. (2015), Agricultural land policy of Ukraine: state legislation and efficiency analysis in Transition to Agricultural Market Economies: The Future of Kazakhstan, Russia and Ukraine, eds. A. Schmitz, W. H. Meyers, Chapter 20, pp. 204-215. https://doi.org/10.1079/9781780645353.0204.

20. Lysak, O. and Andreeva, L. (2017), Problems and prospects of Ukraine's export of agricultural products. Agricultural and Resource Economics, vol. 3, no. 1, pp. 139-151. https://doi.org/10.22004/ag.econ.256886.

How to cite this article? Як цитувати цю статтю?

Стиль - ДСТУ:

Fenghe Z. Analysis of the current situation of agricultural trade development between China and Ukraine. Agricultural and Resource Economics. 2020. Vol. 6. No. 1. Pp. 23-36. URL: http://are-journal.com. 
Style - Harvard:

Fenghe, Z. (2020), Analysis of the current situation of agricultural trade development between China and Ukraine. Agricultural and Resource Economics, vol. 6, no. 1, pp. 23-36, available at: http://are-journal.com. 